\title{
Od folkloru do literatury i z powrotem. Rzecz o wzajemnych inspiracjach folkloru i literatury
}

\section{From folklore to literature and back: On mutual inspirations of folklore and literature}

Pesni literaturnogo proiskhozhdeniya v fol'klore Kemerovskoy oblasti: Khrestomatiya, sostavleniye, predisloviye, primechaniya Viktorii Viktorovny Trubitsynoy, Izdatel'stvo Sitall, Krasnoyarsk 2020.

DOI: $10.12775 /$ LL.3.2021.0012 | CC BY-ND 4.o

Oferowana czytelnikowi antologia opublikowana pod redakcją Wiktorii Wiktorowny Trubitsynej prezentuje unikalny materiał tekstowy z zakresu folkloru pieśniowego obwodu kemerowskiego stanowiący przykład procesu interakcji między literaturą a folklorem. Antologia skierowana jest do studentów kształcących się na kierunkach z zakresu edukacji pedagogicznej o specjalności język i literatura rosyjska. Książka stanowi uzupełnienie szeregu istniejących publikacji edukacyjno-pedagogicznych dotyczących ustnej twórczości ludowej i historii literatury rosyjskiej (np. Anikin 2004; Kostyukhin 2004; Dzhanumova 2007). Zbiór, zgodnie z deklaracją redaktorki, ma służyć pomocą w rozwijaniu 
szczególnych kompetencji zawodowych przyszłych nauczycieli, które związane są z umiejętnością analizy i interpretacji dzieł literackich i folklorystycznych w kontekście historii i kultury, drogi twórczej pisarza, nurtów artystycznych oraz procesu literackiego, jakim jest przekształcanie źródła literackiego w wersję folklorową.

Publikacja podzielona została na dwie części - teoretyczną oraz prezentująca teksty źródłowe, całość zaś uzupełnia wykaz źródeł i literatury. Antologię otwiera wstęp przedstawiający historię rozwoju rosyjskiej poezji śpiewanej w XVIII-XIX w. ${ }^{1}$ oraz oryginalne przykłady porównań źródeł literackich i ich wariantów ludowych, będące pokłosiem pracy badawczej Trubitsynej (2009, 2011, 2012, 2013, 2017). Redaktorka przywołuje m.in. ustalenia dotyczące wierszy Aleksandra Sumarokowa (1717-1777), w których poeta celowo eksponował elementy folkloru. W piosenkach Dziewczyny po gaju chodziły, Nie smuć się, mój promyczku i Wybacz mi, moja droga Sumarokow jako pierwszy wprowadził do tekstu autorskiego ludowy obrzęd (powitanie wiosny i wróżenie z wianków w święto Iwana Kupały). Te motywy stały się później tematem wielu dzieł lirycznych (m.in. Wasilija Żukowskiego i Aleksandra Puszkina). Pod koniec XVIII w. wzrosła popularność gatunku pieśni oraz liczba śpiewników drukowanych. W 1796 r. Iwan Dmitriew (1760-1837) opublikował zbiór zatytułowany Kieszonkowy śpiewnik, czyli zbiór najlepszych pieśni świeckich i ludowych. Rosnące zainteresowanie pieśnią ludową w środowisku poetyckim końca XVIII w. było z jednej strony logiczną kontynuacją rozwoju gatunku pieśni literackiej w kontekście rosyjskiej tradycji folklorowej, z drugiej zaś wiązało się z nowym spojrzeniem na człowieka i koncepcją równości moralnej, głoszoną przez sentymentalistów (np. w opowiadaniu Nikołaja Karamzina Biedna Liza). Przegląd literatury krytycznej i przykładowa analiza wybranych utworów została uzupełniona wnikliwym omówieniem prezentowanego zjawiska przeprowadzonym przez redaktorkę na materiale źródłowym.

Interesujący z punktu widzenia przejścia tekstu autorskiej pieśni pasterskiej do folkloru jest prezentowany w antologii wiersz Puszkina Wiśnia (1815). Ze względu na swoją otwarcie erotyczną treść został on opublikowany dopiero po 42 latach od powstania, ale decyzją Głównego Zarządu Cenzury z tekstu wyłączono siedem czterowierszy o jawnie erotycznym charakterze. Jak wynika z raportów cenzorskich, niektóre wiersze Puszkina, chociaż nie zostały opublikowane, były przekazywane $\mathrm{z}$ rąk do rąk w rękopisach. Potwierdza to m.in. pisemna ankieta dotycząca znajomości utworu poety w środowisku wiejskim obwodu jarosławskiego w 1898 r., która ujawniła obecność w obiegu folklorowym trzech wariantów pieśni Wiśnia. Przykładowo, tekst zapisany od informatorki urodzonej w 1929 r. ukazuje jeden z kierunków przemian tego wiersza - osłabianie

1 Chodzi tu o poezję realizowaną jako gatunek słowno-muzyczny, mimo iż w zamierzeniu twórców nie była przeznaczona do śpiewu. Historia powstania i rozwoju rosyjskiej pieśni literackiej od początku XVIII do połowy XX w., jej odmiany gatunkowe, związki między tekstami piosenek literackich a folklorem oraz zagadnienia wpływu literatury na pieśń ludową zostały obszernie przeanalizowane i opisane w nauce rosyjskiej (zob. np. Lebedev 20oo; Novikova 1982). 
poetyckich szczegółów, uproszczenie fabuły i słownictwa. To typowe modyfikacje mające na celu nadanie tekstowi maksymalnej jasności i prostoty zgodnie z prawami poetyki ludowej.

Niektóre z publikowanych $\mathrm{w}$ antologii tekstów ludowych zachowują wiernie (z niewielkimi poprawkami leksykalnymi i gramatycznymi) tekst pierwowzoru. Wśród pieśni więziennych pochodzenia literackiego taką stabilność wykazują m.in. pieśni Po zakurzonej drodze wóz pędzi..., Przez głucha, nieznana tajgę..., Otwórz okno, otwórz..., Na dzikich stepach za Bajkałem. W tym przypadku pieśń literacka, jako stylizacja na ludową pieśń włóczęgów, zachowuje wszystkie elementy gatunkowe, dlatego jest przyswajana bez korekty. Stabilność tekstu tłumaczy także popularność tych piosenek w radzieckiej kulturze masowej, kiedy to znalazły się one w repertuarze znanych chórów oraz wykonawców pieśni ludowych (np. Nadezhda Plevitskaya, Lidiya Ruslanova, Fedor Shalyapin, Petr Leshchenko, Sergey Sokol'skiy, Zhanna Bichevskaya). Piosenki, przywołując syberyjskie toponimy (np. Zabajkale, Bajkał, Irtysz), w rytmie powolnej przeciągłej melodii opowiadają o wędrówce osoby pokrzywdzonej przez los, bliskiej i zrozumiałej dla większości populacji tego regionu Rosji. Dzięki tym cechom pieśni więzienne często były i nadal są odtwarzane w środowisku i sytuacjach naturalnych dla pieśni ludowych, tzn. jako pieśni biesiadne.

Prezentowana publikacja umożliwia realizację regionalnego komponentu edukacji akademickiej, jednak jej wartość wykracza poza aspekty dydaktyczne, ponieważ jest także cennym źródłem do badań prowadzonych przez filologów i folklorystów. Zaprezentowano w niej inspirowane literaturą teksty ludowe z czterech grup (choć nie wyodrębnionych w strukturze publikacji), które można by określić jako sentymentalno-miłosne, erotyczne, więzienne (wolnościowe) i wiersze duchowe. Przykładowo, w kategorii pieśni więziennych znaczną część współczesnego repertuaru ludowego obwodu kemerowskiego stanowią utwory Siedzę za kratami... (wariant wiersza Więzień Puszkina), Nie słychać hałasu miasta... (wariant Pieśni więźnia Fiodora Glinki), Po zakurzone drodze wóz pędzi... (autor nieznany). Wiersze rosyjskich poetów przeszły także do kategorii ludowych pieśni duchowych, ponieważ obraz modlącego się bohatera w tekstach literackich staje się kluczem do procesu folkloryzacji, np. modlącego się dziecka w wierszu Apolla Majkowa Droga alpejska (1858) czy starej kobiety modlącej się za syna burłaka w wierszu Noc na wsi Aleksandra Krugłowa.

Prezentowane $\mathrm{w}$ antologii teksty ludowe wyselekcjonowano spośród utworów utrwalonych w czasie praktyk folklorystycznych realizowanych w latach 1980-2010 przez studentów Nowosybirskiego Pedagogicznego Uniwersytetu Państwowego, Państwowej Akademii Pedagogicznej Kuzbasu oraz Uniwersytetu Państwowego w Kemerowie. Jak wskazuje redaktorka, specyficzną cechą metodologii badań folklorystycznych na uczelniach pedagogicznych był brak selekcji gatunkowej i tematycznej w trakcie zbierania materiałów. Pieśni były odtwarzane przez informatorów w sposób spontaniczny, dlatego są one dowodem samoistnego bytowania tekstów o rodowodzie literackim wśród ludności Kuzbasu. Materiały prezentowane są wraz z niezbędnymi danymi, takimi jak miejsce 
i rok nagrania oraz informacje o wykonawcach (większość z nich urodziła się przed II wojną światową). Teksty literackich pieśni autorskich oznaczono cyframi, a ich warianty folklorystyczne analogiczną cyfrą i literami w kolejności alfabetycznej. Przyjęty w ramach tomu układ tekstów koresponduje z chronologia powstania literackich pierwowzorów, a równoległa publikacja oryginału literackiego oraz wariantów folklorystycznych ułatwia korzystanie z publikacji zarówno w procesie edukacyjnym, jak i w badaniach naukowych. Przy redakcji starano się zachować wszelkie cechy gramatyczne i dialektalne mowy wykonawców, choć jak przyznaje redaktorka, mogą tu występować nieścisłości, ponieważ dysponowano tylko transkrypcjami wykonanymi przez studentów, a nie nagraniami audio. Niektóre teksty były także przekazane badaczom $\mathrm{w}$ formie pisemnej (rękopiśmienne śpiewniki) lub recytowane przez informatorów, tym samym podział stroficzny oraz obecność lub brak zamierzonych powtórzeń mogą nie odpowiadać melodycznej stronie utworu.

Ludowe pieśni pochodzenia literackiego z początku XX w. były często pomijane przez folklorystów i literaturoznawców jako materiał niegodny uwagi. Współcześnie - jak zauważa redaktorka omawianego tomu - coraz częściej stają się one przedmiotem naukowego zainteresowania. Teksty prezentowane w zbiorze oczywiście nie wyczerpują całego zasobu tego typu materiałów oraz wszystkich dostępnych w archiwach regionu kemerowskiego wariantów i pierwowzorów. Pozwalają one jednak określić główne zasady procesu folkloryzacji i stanowią doskonały materiał ilustrujący zjawisko adaptacji przez folklor źródeł literackich, dlatego też mogą stać się przedmiotem dalszych prac badawczych.

\section{BIBLIOGRAFIA}

Anikin, V. P. (2004). Teoriya fol'klora: Kurs lektsiy. Moskva: Knizhnyy Dom Universitet.

Kostyukhin, Y. A. (2004). Lektsii po russkomu fol'kloru: Uchebnoye posobiye dlya Vuzov. Moskva: Drofa. Lebedeva, O. B. (200o). Istoriya russkoy literatury XVIII veka: Uchebnik. Moskva: Akademiya.

Novikova, A. M. (1982). Russkaya poeziya XVIII - pervoy poloviny XIX v. i narodnaya pesnya. Moskva: Prosveshcheniye.

Dzhanumova, S. A. (ed.) (2007). Russkoye ustnoye narodnoye tvorchestvo: Khrestomatiya-praktikum: Uchebnoye posobiye dlya vuzov. Moskva: Akademiya.

Trubitsyna,V. V. (2009). Fol'klornyye istochniki literaturnoy pesni v poeziia P. Sumarokova. Filologiya i Chelovek, 3, 73-79.

Trubitsyna, V. V. (2011). Retseptivnyye transformatsii stikhotvoreniya A. S.Pushkina «Vishnya» v russkoy kul'ture XIX veka. Filologiya i Chelovek, 3, 186-194.

Trubitsyna, V. V. (2012). Gorizonty interpretatsii literaturnogo teksta v fol'klornykh variantakh: „Umirayushchiy” V. I. Nemirovicha-Danchenko. Folia Litteraria Rossica, 5, 48-54.

Trubitsyna, V. V. (2013). Regional'nyye transformatsii literaturnykh pesen (na primere fol'klora Kemerovskoy oblasti). In M. P. Grebneva (ed.), Altayskiy tekst v russkoy kul'ture: Sbornik nauchnykh statey (pp. 127-134). Barnaul: Izdatel'stvo Altayskogo Gosudarstvennogo Universiteta.

Trubitsyna, V. V. (2017). Motiv molitvy v dukhovnykh stikhakh literaturnogo proiskhozhdeniya (na primere fol'klora Kemerovskoyoblasti). In T. V. Chernysheva (ed.), Altayskiy tekst v russkoy kul'ture: Sbornik statey (s. 100-109). Barnaul: Izdatel'stvo Altayskogo Gosudarstvennogo Universiteta. 